\title{
ASSESSING GREEN HUMAN RESOURCE MANAGEMENT AND ENVIRONMENTAL PERFORMANCE: EVIDENCE FROM GOVERNMENT-LINKED COMPANY
}

\author{
Nurul Liyana Mohd Kamil, ${ }^{,}{ }^{*}$ Nur Hairani Abd Rahman'1, Mohd Hasrul Mat Yusof ${ }^{1}$ \\ Faculty of Economics and Administration, Universiti Malaya, 50603 Wilayah Persekutuan Kuala Lumpur, Malaysia.
}

ABSTRACT - Environmental performance is a new initiative to reduce natural disasters as a result of climate change. To foster environmental performance among employees in the organization, green human resource management is one the prominent functions to mobilize the green culture. This study sought to assess the impact of green human resource management (in the form of green recruitment, green training and development, and green performance management) on the environmental performance among employees in government-linked company via a qualitative research approach. Using thematic analysis, in-depth semi-structured interviews are utilised to arrive at conclusions with regards to the performance of the environment by assessing green human resource management. Research findings demonstrated that the green human resource management significantly opens more opportunities to the government-linked company to succeed in its environmental performance and simultaneously receives more recognition in terms of environmental certifications and awards. Most respondents agreed that the green integration to its human resource function contributes to more awareness among the employees on the environment. While some respondents stated that they faces few difficulties to maintain it but there are always solutions to overcome the issue. In conjunction with these findings, this study strongly recommends to all public sectors and public agencies to implement the green practices within the aspects of human resource. It does not burden the human resource functions, it even helps the organisation to reduce cost and save the environment.
ARTICLE HISTORY

Received: 23-7-2021

Revised: 13-8-2021

Accepted: 6-11-2021

\section{KEYWORDS}

Green human resource

management;

Environmental

performance;

Government-linked

company

\section{INTRODUCTION}

The concept of environmental sustainability has been widely discussed by Western literature for two decades. Hueting (2010) defined environmental sustainability as "the function of the environment is very important to ensure that the ecosystem can be safeguarded for future generations". Indeed, the slogans such as "Go Green" and "Save our environment" used by the media to promote awareness on saving the environment campaign to society by having a great environment and a healthy lifestyle is effective. There have been numerous cases such as haze and bushfires, and every country in the world should be environmentally conscious. As a result, many initiatives have been taken by the government and NGOs to protect the environment. In Malaysia, the government displays full support to take care of the environment. For instance, the establishment of the Department of Environment under the Ministry of Environment and Water as the current government changed with the implementation of the Environmental Quality Act 1974 then the Environmental Quality (Amendment) Act 2007, and the Environmental Quality (Amendment) Act 2015. Furthermore, the Department of Environment has taken decisive action Under Section 29 (A) of the Environmental Quality Act 1974 against the offender who committed open burning to prevent global warming, haze, destruction of forests, destruction of animal habitat, and human health. Significantly, the ministry's establishment and actions are moving people in the direction of environmental preservation.

In essence, each organisation, manufacturing, and other small company must participate in environmental preservation. The organisation can practice environmental preservation by implementing green activities to help and save the environment. To maintain the sustainability of the organisations, they must take good care of the triple bottom line which is people, planet, and profit. From the triple bottom line, it is indicated that the planet must be taken care of for the sustainability of the organisations. It can be measured on the organisation of its environmental performance. Examples of the organisation's practices to save the environment are reducing paper usage, using hydrogen cars instead of petroleum cars, and meeting virtually via Skype or online conference. The other way that the organisation can do for the environment is through corporate social responsibility (CSR). CSR is one of the important aspects of the sustainability of the organisation. Through CSR, the organisation can ask the employees to do a cleanliness program or recycle program in many areas. It can be one of the initiatives to encourage them to become more environmentally friendly. It is not difficult to make the employees to be more aware of the environment. Thus, human resource is needed to identify the strategies to ensure the employee will get their best and do the best for their organisation. 
To ensure that all employees will support these green activities in the organisation, human resources will exhibit their support for green through Green Human Resource Management (hereafter referred to as GHRM). The definition of GHRM is accountable for producing a green workforce that understands, appreciates, and practices green initiative and preserves its green objectives throughout human resource management (HRM). It is reflecting the process of recruiting, hiring, training, compensating, developing, and advancing the companies' human capital (Jerónimo, Henriques, Lacerda, da Silva \& Vieira, 2020). Green human resource is a blueprint of how HR managers manage to support the green activities and ensure that all employees have done their role to save the environment through this GHRM. Green human resources are not that different from conventional HR practices. This green practice is all about how the organisation takes action on sustainability and earth-friendly practices. Human Resources also play its role to ensure the organisation will become one of the organisations that support and save the environment (Guerci, Longoni \& Luzzini, 2016). It involves green recruitment, green training, green performance management, and other related to human resource management in practicing green and earth-friendly organisation. On one hand, to raise awareness of this issue among all people throughout the world, management must take action and go green in order to aid climate change. On the other hand, human resource management is responsible for instilling and putting out the effort required to practice GHRM.

Many organisations are now implementing GHRM in their operations. However, some organisations still do not practise it. The reasons are some organisations do not have adequate knowledge on how to start this GHRM practice at their organisation. Besides, some organisations think that this practice will add a burden to the organisation because they have to incorporate new practices in their HR functions. Furthermore, there are also some organisations that are not aware that they already practice the GHRM in their organisation. This research will assist them on the steps taken by other organisation that already have practice GHRM and show them the effectiveness of this practice in their HR function especially in the environmental performance of the organisation. Green practice needs to be integrated with the HR functions which involve recruitment, training and development, performance management, and benefits. If all the public sectors implement this, it will set a good example to all organisation and private sectors to follow suit and get great feedback and results. In addition, GHRM is related to the environment, it can clearly give the organisation one initiative to prove the organisation is committed to saving the planet from natural disasters. It is important that they demonstrate their commitment to environmental protection and the prevention of climate change. It is upsetting that there are still people who do not care about the environment and do not wish to be environmental saviours. Thus, human resources may go green in all of their departments, including recruitment, training, and performance management. It can be carried out as usual while being environmentally friendly. Because the environment is important to us and for the future generation, it requires the assistance of all employees to be aware of and sensitive to it. Therefore, this study attempted to assess the relationship between GHRM and environmental performance. This research does not cover all the HR functions. It only covers recruitment, training and development, and performance management.

The following research questions were addressed while conducting this study:

(a) What are the implementations of the GHRM (in the form of recruitment, training and development, and performance management and benefits)?

(b) How about the participation of employees with GHRM practices?

(c) What are the impacts of GHRM on environmental performance?

Therefore, the following contributions to the existing literature are made as a result of this study's investigation of these concerns. First, it contributes by investigating the organisational antecedents of environmental performance from the employees' perception of GHRM practices. Second, by defining GHRM practises as internal sources to improve employees' environmental performance, this study expands the resource-based view and ability-motivation-opportunity of HRM into the GHRM domain. Last but not least, this study provides empirical evidence from the Malaysian context on the impact of GHRM practices on employee environmental performance.

\section{Green Human Resource Management And Its Relationship With Environmental Performance}

Based on the UK Survey data reports, environmental performance must be one of the most significant components to consider in an organisation's reputation. It was highlighted that exceptional graduates have picked environmental performance and organisations' reputation as factors to consider while looking for a job (Yusliza, Yong, Tanveer, Ramayah, Noor Faezah, Muhammad, Faezah, \& Muhammad, 2020). Furthermore, environmental performance refers to the evaluation of the relationship between the organisation and the environment (Olsthoorn, Tyteca, Wehrmeyer \& Magner, 2001). It epitomises the quantification of the effectiveness and efficiency of environmental action with a set of metrics (Neely, Gregory \& Platts, 1995). The indicators act as surrogates or proxies for organisational phenomena (Ijiri, 1975). Apart from that, environmental performance refers to a reduction of waste release/generation/emission as a result of certification (Nemati, Zheng \& Hu, 2016). Corporate environmental performance is described as the effect of the organisation on the environment (Šimberová Chvátalová, Kocmanová, Hornungová \& Dočekalová, 2015). Environmental performance is one of the measures used to assess the situation of the environment in relation to all organisational activities (Shahabadi, Samari \& Nemati, 2017).

Therefore, all organisational activities such as supply chain management, have an impact on the environment as it affects the product life cycle (Jermsittiparsert, Sriyakul, Sutduean \& Singsa, 2019). Environmental performance can be defined as the organisation's actions in environmental management that serve as a benchmark for the organisation, and 
its financial performance. The organisation will report on its environmental performance in terms of carbon footprint, environmental accomplishments, and so on.

\section{Green Recruitment and Environmental Performance}

In every organisation, recruitment is important to HR management. The purpose is to discover the best candidate for the job who will contribute to the organisation's success. Green recruitment is one great effort for HR to practice in the organisation in order to maintain sustainability and environmental responsibility. Green recruitment is the hiring of people who are aware of and concerned about environmental issues, and who are likely to contribute to an organisation's environmental management (Jabbour \& Renwick, 2020). Apart from that, green recruitment refers to a recruitment process that does not use paper and uses online media such as Skype, video calls, and other green recruitment technologies instead (Selvi \& Ellisha, 2015). Green recruitment is also defined as becoming a green employer or green employer of choice (Renwick, 2013). Besides, HR can also include environmental criteria in recruitment posting of the vacancy and inform the employer's concern about green aspects in the recruitment process (Opatha, 2013). As a result, the candidates will choose the company that practices green in its company because it will prove how high-quality and sustainable the organisation is based on its recognition either in certification or the media. Besides, green recruitment is a system that indicates the objective of the organisation in nurturing the protections and caring environmental behaviour.

To ensure green recruitment, HR managers must instill the attitude of environmental saviour within themselves, rather than simply following top management instructions to become green personnel. It is not just about policy; it is about aligning our daily lives as humans with the organisation's environmental performance. Recruiting employees with a green attitude can help the organisation to sustain its environmental performance and it is also good to influence other existing employees. (Araganathan, 2018). Previous scholars suggested that organisations need to balance the financial performance and the preservation of the environment at the same time because it has been assured that by supporting the green practices, companies may achieve profit more (Daily \& Huang, 2001; Murari \& Bhandari, 2011). Green recruitment can also save more time and energy to HR recruiters and the applicants as they only conduct the interview via video conference and do not need to fill in paper forms. It also can reduce paper usage in the organisation. Not just that, the green employee can help the organisation to become more productive, care for the environment, and voluntarily conduct environmental activities. It is good for the environmental performance and the sustainability of the organisation. Thus, green recruitment in green human resource management can have a great impact on environmental performance, especially in finding a green employee to work in the organisation. A study shows that green recruitment attracts more and better job seekers (Guerci et al., 2016). More people are concerned about the environment in this new generation than in the previous ones. As a result, people will go to an organisation that is environmentally conscious. As a result of the foregoing, the following hypothesis is proposed:

Hypothesis 1: Green recruitment has a significant impact on environmental performance.

\section{Green Training and Development and Environmental Performance}

It is the job of human resource management to provide training and development to employees. Training and development are essential for managing talent and enhancing employees' abilities. In terms of environmental support and preservation, the organisation can practice green and integrate it in training and development. Then, it will be an example of green training and development, which is beneficial to the organisation's long-term viability. One of the most important instruments in developing human resources is environmental training (Jabbour, 2011). Green training is defined as "providing employees with the required knowledge about an organisation's environmental policy, procedures, and attitudes" (Jabbour \& Renwick, 2020). Furthermore, green training entails providing an opportunity for all employees to receive training in environmental management (Opatha, 2013).

Training is needed to provide to all staff about the environment as they need to know how they can save the environment by only doing small things. Training is to provide knowledge to the employees and enhance their skills. Furthermore, the purpose of green training and development is to develop and create awareness of the employees on the importance of caring for the environment. It also builds competence to reduce waste and save energy among the employees. Green training is very effective in supporting the environmental management system performance (Sarkis et al., 2010). It also becomes the key to the success of the implementation of the environmental management system and produces a green culture in the organisation. Perron, Côté, and Duffy (2006) suggested that it is significant for the organisation to practice specialized and customized green employee training and also assess the effectiveness of the training program with a valid instrument. Furthermore, Renwick et al. (2013) proved that certain practices to be included in the training programs to appreciate how to save the environment, training on recycling energy through effective way and safety and green in the workplace, waste management, environmental training and programs, and job rotation for potential green managers within the organisation. These training programs should be done based on training needs to achieve the best environmental well-being from the training (Cherian \& Jacob, 2012). As a result of the aforementioned reasons, it is proposed that:

Hypothesis 2: Green training and development have a significant impact on environmental performance. 


\section{Green Performance Management and Environmental Performance}

Performance management is a relatively new concept that has been emerging in Western literature since a decade ago. As one initiative to grow personnel, performance management totally supports it (Aguinis, 2013). In addition, performance management entails "identifying, measuring, and developing the performance of individuals and teams; and aligning performance with the strategic goals of the organisation" (Aguinis, 2013). Performance management is supporting the employees and the organisation itself to achieve the target and give a great result for the organisation in return. Furthermore, Cheah, Prakash, and Ong (2020) demonstrated that the purpose of performance management is to cultivate the performance of employees and the organisation. One of the tools for this performance management is the Key Performance Indicator (KPI), which requires employees to meet the KPI's objective in order to ensure that their performance in the organisations is excellent and they receive rewards and appraisal for it.

Performance management is one of the important components of HRM which provides input to other HR systems and processes such as increments, rewards, promotions, training, and career development. It shows in every article that performance management is important to boost the performance of the employees to achieve the organisation's goals. In organisations, superiors and managers need to provide information to the workforce in terms of performance (Pulakos, 2004). The employees need to inform on what they should achieve for their performance. The main purpose of performance management is to guarantee that employees and organisations concentrate on the same priorities (Performance Management, 2019). The performance management approach utilizes particular and systematic evaluations, provides specific performance feedback to improve employee performance, identifies the training requirements needed for employee development and promotion, and facilitates individual and organisational development. Employee decisionmaking and performance establish a close relationship and it indeed increases employee motivation and productivity. In implementing performance management, an organisation must first form a clear idea of several important aspects. It has long been recognized that performance measurement and management are very important for effective and efficient logistics network management (Melnyk, Bititci, Platts, Tobias \& Andersen, 2014).

Performances measurement and management contribute to continuous performance improvement (Neely, Gregory \& Platts, 1997), for the dissemination of strategies (Kaplan and Norton, 2001), to organisations learning (Kueng, Meier \& Wettstein, 2001), and to management development (Garengo, Biazzo \& Bititci, 2005). Ramgopal and Jha (2019) argued that performance management can be related to the financial management of the organisation which is a continuing process to manage the finances of the organisation while the annual audit that evaluates the financial performance of the organisation is an annual event which is periodic. It can also be linked to employees Quality Assurance evaluation. Therefore, green performance management is appropriate for organisations to adopt and apply to each of their employees in order to provide better environmental performance. Hence, the following hypothesis is developed:

\section{Hypothesis 3: Green performance management has a significant impact on environmental performance.}

Therefore, the research model is shown in Figure 1 in accordance with the aforementioned literature review and hypothesis development.

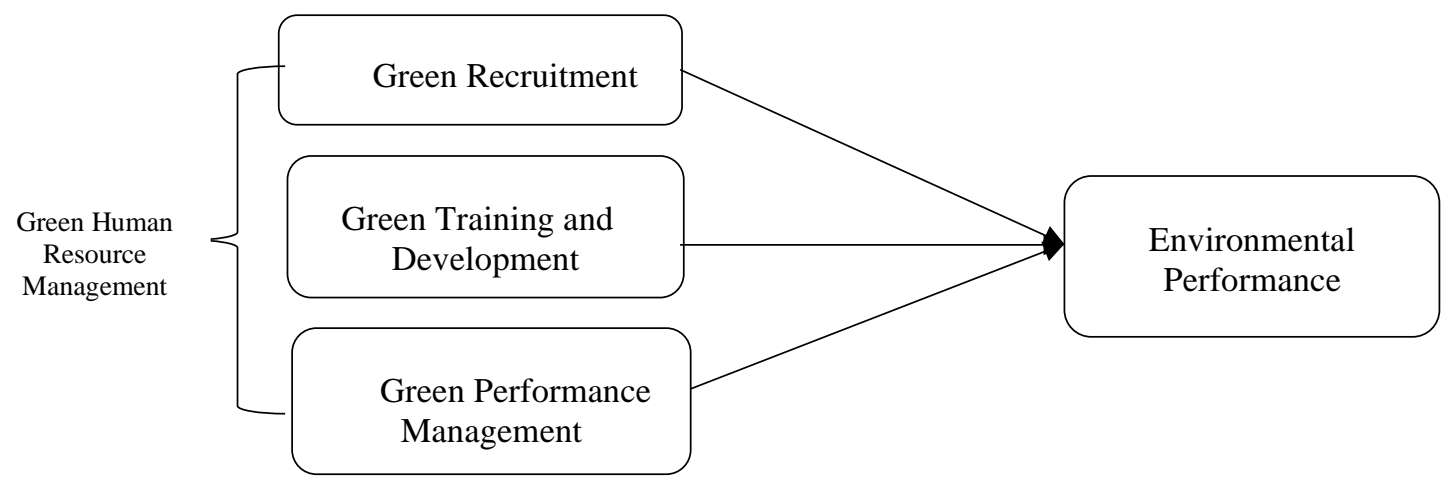

Figure 1. Research Model

The resource-based view theory by Barney (1991) is a framework in management that is used to determine the strategic resources of an organisation to attain a sustainable competitive advantage. Based on RBV'S theory, the firm's resources are the tangible and intangible assets that are tied (see Figure 2). "These resources are valuable, rare, and cannot be easily imitated by others" (Yong, Yusliza, Ramayah, Chiappetta Jabbour, Sehnem \& Mani, 2020). Each organisation will apply the input differently based on how they want to shape its organisation. In the end, the organisation will show sustained competitive advantages as the organisation has proven its efficiency and its output meets the demands. The organisation must know how to utilize the resources wisely to show their best in managing the organisation.

To ensure that the organisation can be sustained as a competitive advantage organisation, HRM plays an important role to manage the employees as its value for the organisation. Koch and McGrath (1996) studied the relationship between HR planning, recruitment, staffing practices, and labor productivity. They argued that "a highly productive workforce is 
likely to have attributes that make it a particularly valuable asset to the organisation" (Koch \& McGrath, 1996). Thus, for the organisation that practices a green environment, HRM needs to be aligned and support the management to implement this policy in the organisation. It will be HR's responsibility to ensure the success of the implementation of green in the organisation. The organisation needs to produce more "green employees" in accordance to having a more resourceful human resource which is one of the sources in the organisation to sustain the competitive advantage for the organisation.

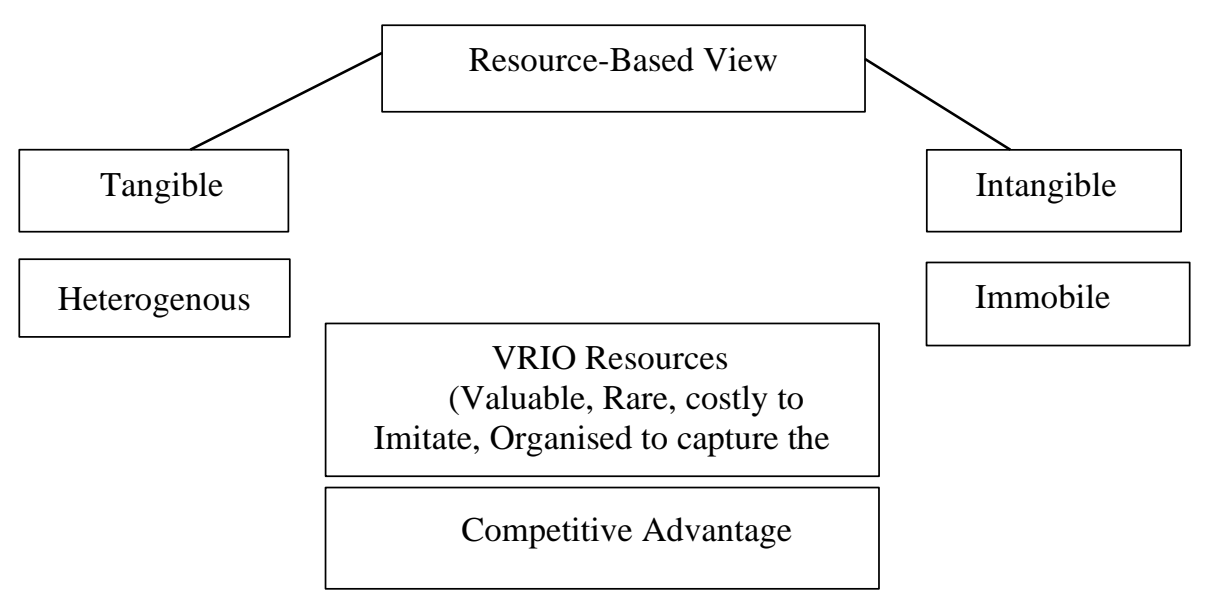

Figure 2. Resource-Based View Theory by Rothaermel (2012)

Ability, Motivation, and Opportunity theory by Bailey (1993) is significant to HRM practice to explain the relationship between how employees are managed and their performance outcomes (Kellner, Cafferkey \& Townsend, 2019). The formula for this theory is how the employee's ability, motivation, and opportunity can determine their performance in the organisation as indicated in Figure 3. It shows how HRM practices can influence the employee's ability, motivation, and opportunity that can affect their performance. The employee's effort is ensured according to three mechanisms: (a) employees needed to have the required skills (b) employees needed good motivation; and (c) employers had to accommodate them the opportunity to contribute (Appelbaum, Bailey, Berg, Kalleberg \& Bailey, 2000). It can be shown how GHRM can give a positive impact on the employee to become an environmental saviour. In terms of GHRM, the employees can show their ability through green training, motivate the employees with green Performance Management, and give them the opportunity of becoming a person who is more aware of the environment and be measured by the organisation's environmental performance.

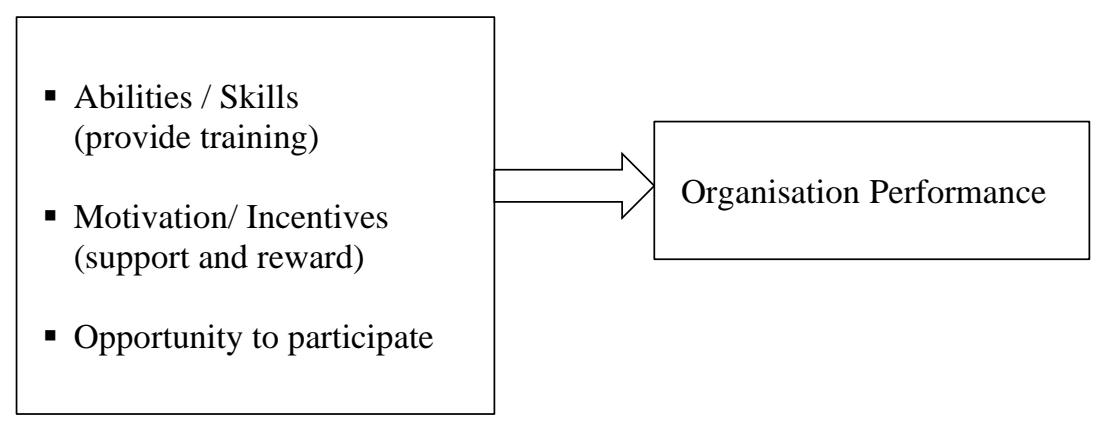

Figure 3. Ability, Motivation, and Opportunity Theory by Appelbaum et al. (2000)

It is compulsory to merge environmental management and HRM in every country. GHRM is one of the great policies to have in the organisation to ensure more eco-friendly people on this earth. The green initiatives would be very operative because labour is often a huge contributor to waste and pollution, especially for the service-oriented organisation. It is an operational level responsibility, but HRM can also be the reviewer to all the activities and provide the guidelines on GHRM. Yusmani and Yusliza (2015) argued that GHRM is a platform that supports creating a green workforce that can understand and appreciate the green culture in an organisation. 


\section{METHOD}

\section{Participants}

This study employed in-depth semi-structured interviews with an HR professional to describe how HR in a government-linked company performs GHRM. For this research, the study was conducted in PLUS Malaysia Berhad. There were 10 respondents including three representatives from HR departments, two officers who are in charge of MyGHI and ISO 14001:2015 with the positions of (a) HR Executives, (b) Deputy Senior Manager, QMCM; and (c) Executives, QMCM; and five highway users. Due to the COVID-19 pandemic, the interview was conducted online based on the prepared questions to the personnel. An interview is an appropriate method when there is a need to collect detailed information on people's views, thoughts, experiences, and feelings (Easwaramoorthy \& Zarinpoush, 2006). Therefore, this interview is important as it helps to get useful information for the research. They shared some of their practice of green human resources on its environmental performance. The interviews lasted for about 45 minutes for each informant.

\section{Data Collection Procedure}

There were procedures that the researcher must follow to ensure that the researcher obeys the integrity of the research. Informing the interviewees about the motive of the research and its essential characteristics are the main criteria of endorsement. Besides, the data that could lead to the identification of the respondent such as names and personal details were not taken into records. The researcher needs to acquire approval from the respective PLUS Malaysia Berhad Director beforehand. Then, a researcher prepared the cover letter and sent it to them for their consent and to inform them that there is no right or wrong during the interview session. After obtaining approval, an interview guide was developed to carry out an in-depth interview with participants consisting of six parts. The interview questions were divided into two perspectives which are the employees that in-charge in the department itself and the highway users. The researcher needs to get two different views from these two interview questions. From this research, the comparison between these two views can be shown as we can get the customer experience on the highway, rest area, and layby. For the first part of the interview guide, researchers asked each respondent to describe working details such as their current positions, brief job description, and length of working in the current organization. In the second part, each of the respondents had to explain their understanding of green human resources management. Furthermore, the interview session was focusing on MyGHI caretaker related to the environmental performance at PLUS Malaysia Berhad. The questions from this part attempted to elaborate on the impact of GHRM practices on environmental performance. The questions were developed to understand the concept of ISO 14001:2015, the environmental management system certification, and the concept of Green 5S that has been introduced by PLUS Malaysia Berhad towards their environmental performance. At the end of the interview session, each respondent was asked about the knowledge and awareness of PLUS green practices to the infrequent highway users.

\section{Data Analysis}

In this study, the researcher has taken validity and reliability as an important result to ensure the research can be useful and be a good reference. To ensure the validity of the research, all aspects must be taken care of. Thus, the researcher ensured that all the interviewees will give the answers independently without any biases. The researcher semistructured the interview questions and the questions were sent to the expert in the HRM field for further approval. It is to ensure that the questions have been constructed based on the context of this study. The researcher chose content analysis to analyse each answer given by the respondents.

\section{RESULTS AND DISCUSSION}

A total of eight females and two males were interviewed representing the employees and users. The majority of the females are coordinating the Quality Management especially for the ISO 14001:2015, MyGHI, and Green 5S. Next, looking at the working experience group among the respondents, five people have less than five years of working experience which comprises about $50 \%$ of the total respondents, followed by people who have been working for more than five years (20\%) and the balance are those who have been working for more than 10 years $(30 \%)$.

\section{Results for RO 1: To identify the implementations of green human resources management (in the form of recruitment, training and development, and performance management) in government-linked company}

From the interview session, the respondents suggested how government-linked company dedicated their green practices in the process from application for new employees until the appointment of the candidate. For instance, Informant 1 mentioned that:

\section{"In terms of environmental job scope, the organisation will normally recruit applicants who have an environmental background”.}

Besides, Informant 2 and Informant 3 who are responsible for recruitments share their process of recruitment. They mentioned that there are at least five processes involved in the recruitment of employees: (a) request for a new employee 
- All the managers or supervisors are already aware that if they would like to request a new employee for their department, they need to make a request in the system. The system is called the Oracle System. It is also called Talio System as the managers or supervisors need to key-in details in the system pertaining to requesting for a new employee, (b) sourcing the candidates - the HR will set-up and arrange the interviews with the candidates either via face-to-face interview or einterview, (c) request for appointment (approval from management) - if the candidates are selected, the HR will forward the decision to the management for approval and signature. The signature will be an e-signature and it will be in soft copy; and (d) on-board - after getting approval from management, the HR will call the appointed candidate to inform and email the soft copy form to the candidate to be filled in. Then, they will forward the form to the payroll unit. Based on the information, it is shown that the government-linked company is committed to green practices, where they hire candidates who have environmental expertise to suit the mission and vision of the organization. Besides, in the recruitment process, the company is most likely using soft copy instead of hard copy in its recruitment process. It proves that HR in the government-linked company has less paper usage in the process of HRM itself. Technology innovation such as big data analytics helps to ease the system of recruitment at their organization. It also at the same time helps the environment by not using paper. The applicants do not need to travel to the workplace and fewer carbon emissions are released to the environment. It is proven that GHRM can be exercised with the assistance of technologies such as the internet and software. Employees nowadays need to be friendlier with the technologies in accordance with the Industrial Revolution 4.0.

The second important function in HR is to ensure the employees become more effective and developing. Informant 1 asserted that:

"HR division does provide some training on the environment to all staff. Besides, HR is also committed to assisting the Quality Management Unit in conducting the training for the environmental management system, including the internal auditor, implementation, and awareness of environmental management systems such as ISO 14001:2015, Green 5S, and MyGHI”.

This statement supported that HR requires the environmental training planned by the respective unit such as the Quality Management Unit (QMU). The training shared valuable information that requires organisations to comply with the implementation of the Environmental Management System. Selected employees, particularly the environmental engineers will be attending the training. All the training is initiated by the QMU as suggested by DNV GL Sdn. Bhd., but then it will be preceded and conducted by HR. Furthermore, the response from Informant 2 and Informant 3 added that:

"In order to ensure that the HR process is still ongoing even during the pandemic, we are required to conduct online training, meetings, and most programs. We also have the portal for HR which is MyHR" and "HR does share awareness on environments in the portal MyHR to all staff. In fact, we are also encouraged to spread awareness via social media and e-flyers".

Thus, all the activities are mostly done through an online medium which is good to practice green in the company. Employees do not need to travel by car, and it could save the environment itself by less use of carbon. The respondents also added that during the pandemic, the use of Zoom and Microsoft Teams in online training is applicable for most purposes due to the effectiveness of the online medium. From the research, employees at the government-linked company will be exposed to the environment when they become a member of the EMS committee or internal auditors. Furthermore, most of them have an environmental background. From the training, they will know more about the importance of the environment and steps to be taken even in your organization. Besides, during this pandemic, the organization practices online training that can help to reduce wastes and pollution in comparison to physical classroom training.

Apart from that, to succeed in the green practices in HRM, performance management can be the best function to integrate with the green practices. Some of the respondents have responses related to green performance management. They stated that:

"For performance management, HR has the item for the environment in the Key Performance Indicator (KPI) to all employees. HR will record the data using soft copy through the HR system, and this will reduce the paper usage in the company."; and "If the employees do not fulfil the KPI for the environment, the merit will be deducted, and it will affect the employees ' yearly bonus."

Based on the statements, it also demonstrated that the government-linked company has shown its commitment to ensuring all of the employees are complying with the item for the environment, particularly for the KPI itself. Thus, the employees will do the responsibility to take care of the environment from this item insisted by the company. The integration of green practices in HR performance management is excellent to ensure that employees show their support for the environment. 


\section{Result for RO 2: To assess the impacts of green human resource management on environmental performance}

This study assesses how GHRM will be impacted by environmental performance on its organisation. The Environmental Management System (ISO 14001:2015), Malaysia Green Highway Index (MyGHI), and Green 5S are three indicators that include the environmental approaches in the organisations. The questions had been asked in the respective departments to ensure the success of these three indicators which include Quality Management and Concession Monitoring Department. The PLUS Malaysia Berhad has been certified the Environmental Management System (EMS) or known as ISO 14001: 2015. The organisation will have an annual audit from DNV International for its certification. The purpose of this indicator is to be recognized as the organisation that manages the environment properly in doing their daily work. Before the external audit, the committee will be having the internal audit for the preparation to do the corrective action. This is supported by Informant 1 statement:

"Our company has an EMS Council to monitor environmental performance. Same as Quality Management System $(Q M S), E M S$ also has the manual procedure and objective target. The committee has to monitor if they comply with the environmental act or not. The Environmental Act must be related to PLUS Malaysia Berhad. We must fulfil the requirement regulator procedure. At PLUS, the dedicated department for the EMS is the Healthy, Safety, Security and Environment (HSSE) department."

Therefore, for the implementation and challenges of this Environmental Management System (EMS), few informants argued that:

"The implementation of EMS so far is excellent. Every committee has shown its support for EMS. Since it is stated in their job description and also have the item for the environment in their KPI. The selected employees as the internal auditor need to participate in the training and internal audit. They need to make sure all the daily work comply with the EMS standard."

"The audit is done mostly at the site, in terms of chemicals management. The challenges in this implementation of EMS are compliance with the standard. Controlling outsourcing is important to make sure that they comply. Besides, the operations also rely upon the management."

\footnotetext{
"The management needs to monitor the performance of all operations at PLUS Malaysia Berhad. To ensure this implementation of EMS is going well, the company requires competent persons to manage this environmental management system."
}

This affirmation indicated that complying with the ISO 14001 standard is a challenging and difficult task to implement more effectively. However, based on support from employees, particularly from the operations division, they gave much cooperation in fulfilling the EMS. HR needs to make sure that only talented and competent employees will be hired to manage the EMS accordingly. That is why the training is proposed by the QM unit to HR to approve and proceed with the respective trainer. EMS council has shown their commitment to the environment since then to make sure that PLUS has complied with the standard not only for the company but also for the environment itself.

The second indicator for environmental performance at a government-linked company is called Malaysia Green Highway Index (MyGHI). MyGHI refers to recognition for the highway concessionaire in Malaysia for practices green at its highway. The PLUS Malaysia Berhad is one of the highway concessionaires that is actively involved in achieving the award for Green Highway Index recognition. MyGHI is initiated by the result of the concerted effort and contribution of researchers and highway experts, and implementation by the MyGHI. The process of audits is more to the documentation that involved the operation in handling the green highway. Some of the respondents gave feedback such as:

"Malaysian Highway Authority already provides the guideline towards MyGHI Assessment and company green indicator. The operation together with the Quality Management unit must identify a green index that will help us to achieve the green highway objective. For the support, we are glad that we have received full support from all the employees. For the challenge, yes, we face the challenge in implementing MyGHI which is the guideline that was newly created after the PLUS highway had already been there since 1986".

In addition, Informant 1 further explained that it was a challenge to comply with the new guideline of MyGHI. Most of the requirements are new for the organization and it is costly for the documentation. There are many types of documentation that need to be provided for the MyGHI process. Furthermore, the biggest challenge in implementing MyGHI is it involves high cost and the need to comply with many documentations as it is a new initiative that is suitable for the new highway. However, from the good practice of GHRM, the employees manage to contribute and support this MyGHI until the organisation receives the awards for MyGHI as mentioned earlier. From GHRM, the employees notice and are aware of the actions needed based on the implementation of MyGHI in the organisation. With this GHRM, the employees tend to have more ideas to provide green practices for the highway. 
Additionally, Green 5S is a third indicator of the green practices that were implemented by the government-linked company. The Green 5S is more focused on all rest and service areas (RSA) and layby under PLUS management. It will provide the certificate to all stalls and place it on its Green 5S practices. The Green 5S is about arrangement, cleanliness, and safety. It is important to provide excellent services to customers. PLUS Green 5S is also under the management of the Quality Management Unit. PLUS chose SIRIM STS Sdn. Bhd as the external auditor to give PLUS the recognition of Green 5S at the company. The customers who come to the RSA or layby will notice the certificate and the good arrangement, cleanliness, and also the safety. These are some responses from the informants who are responsible for this certification:

"For Green 5S, we only focus on RSA and layby along the PLUS Highway. Our responsibilities are to monitor all the stalls, the labelling, the signage, the arrangement of foods and drinks, first aid kit, the safety, and cleanliness of the area and toilet."

In fact, another informant added that:

"Before the external audit, we will do the internal audit. If the auditor found any findings, they need to do the corrective action within two weeks before they give the certificate. The certificate is valid for a year. The participation, some of them can comply all the time, and some of them only comply during the audit."

From these responses, this Green $5 \mathrm{~S}$ is an excellent initiative to ensure that the company provides excellent service to its customers. It is also for the safety of the employees and customers. Green $5 \mathrm{~S}$ also brings the green practices in $5 \mathrm{~S}$, one of the Quality Management tools. It is effective to ensure that all the employees and stalls renter will give a better and conducive rest and service area or layby along the PLUS highway. The internal audit conducted by the Quality Management Unit is very good to ensure that any findings have been corrected before the external audit by SIRIM STS Sdn. Bhd. Interestingly, all stalls at PLUS RSA and layby have the certificates of Green 5S practice.

\section{The Perspectives of PLUS Highway Users on Green Practices at PLUS}

This study also targeted to interview some of the PLUS highway users on their perspective for PLUS's GHRM practices. From the interviews conducted, most of them were aware of the implementation of green practices and two of them were not aware of this. The respondents were frequently using the highway either from northern or southern. In terms of the services of RSA and layby at PLUS highway, the respondents were satisfied with the services. Some of the respondents gave a 4-star rating and some of them gave a 5-star rating. It is exhibited that the RSA and layby at PLUS Malaysia give great services to their customers as they have the legendary experiences as the oldest highway in Malaysia. However, in terms of green practices, there were different perspectives on the practices at PLUS. On one hand, the respondent who was aware of the green practices at PLUS highway said that:

\section{"I am aware and know the green practices, but I did not notice the green practices at the RSA and layby. I think PLUS should have shown more the green practices to the users for them to notice such as signage or any information on green practices."}

Informants who were not aware of PLUS's green practices, on the other hand, claimed the opposite:

"I am not aware and do not know much about the green practices, but I did notice the green practices at the RSA and layby. The PLUS already has the EV Charging Station for the hybrid car at Ayer Keroh Rest Area and Service Area and uses solar energy at Machap Rest and Service Area. I think that is good initiatives of green practices at PLUS highway."

Based on these feedbacks, it indicated the differences in their perspectives on the green practices at PLUS highway. Some of the respondents did not notice at Northern highway, but the other respondents' noticed at Southern highway. PLUS needs to have more green practices such as more recycling bins and green signage that is suitable for adults and kids that notify the customers in terms of providing good services and creating awareness on the green practices.

\section{CONCLUSION AND IMPLICATION}

In a nutshell, this study exposed the significance of GHRM practices at one of the government-linked companies in Malaysia which are PLUS Malaysia Berhad. It demonstrated that Malaysia is already committed to protecting the environment through the implementation of GHRM in organizations. The independent variables in this study are green recruitment, green training and development, and green performance management. The integration of green practices in HR functions can be helpful to create green awareness for all of the employees and for the company that takes care of their environmental performance. The balance of financial and environmental performance helps the sustainability of the organizations. For instance, the case study at PLUS Malaysia Berhad helps the organization to achieve the success of the implementation of green practices such as EMS, MyGHI, and Green 5S. It is revealed that the GHRM also contributes to the success of the recognition that PLUS had today. EMS is the certification that proves PLUS has the support and protection of the environment within the organization. Also, MyGHI is about the Malaysia Highway Authority initiatives 
of green practices that involve the green practices of all the highways in Malaysia. Finally, the Green 5S practice also has the integration of green practice. It is from the Japanese practice of efficiency of the workplace and also for the arrangement and standardization. Besides, this study received some opinions from the highway users on the green practices at PLUS Malaysia Berhad. Some of them were aware of the green practices and some of them were not aware much about the green practices. Moreover, for the recognizable green practices at PLUS RSA and layby, some of them noticed and some of them did not notice the green practices by PLUS. The respondents also shared some ideas for PLUS to be recognized as the company that does green practices. The research can be a guideline to prove the success of the green practices and for other organization either public or private sectors to implement GHRM.

\section{LIMITATIONS AND SUGGESTIONS FOR FUTURE RESEARCH}

This study encountered some limitations that offer an agenda for future research. The first limitation is this study was carried out during the pandemic COVID-19 period. Thus, the researcher had to face some struggles to get the information and it was a difficult task to deal and interact with PLUS Malaysia Berhad without an appointment and need to follow the standard operating procedure to meet the interviewee. To conduct the interview, the researcher needed to fill the form and prepare the required documents for consent before starting the interview. Furthermore, the employees were already working from home due to the pandemic. So, the limitation of this study is that it is difficult to directly contact the person in charge of PLUS Malaysia Berhad as they have to work from home. However, the approaches that can be applied to contact the person in charge are follow-up through email by sending formal letter and consent of interview. Fortunately, some of the employees had an interview with the researcher. The department itself managed to provide two HR executives for the GHRM interview and another four from the Quality Management unit. The interview with the respective interviewees was done perfectly. The researcher did not do the interview via face to face but through telecommunication mediums such as phone calls, Google Meet, and Microsoft Teams. It helps the researcher to get the data and information for the research.

As for the suggestion, future research can conduct the study using a variety of targeted organisations and respondents' levels. This present study only focused on one of the GLCs in Malaysia. It is highly recommended for future research to target respondents from the public sector or private sector. It enables more participation of respondents and discursively, this will increase the reliability and validity of the research outcomes. Generally, respondents from different levels or sectors will give disparate perspectives and opinions as well. This research can be improved with focuses on the challenges of GHRM practices and how the organisation overcomes the challenges in detail. Thus, it can convince other organisations that there are many ways to overcome the difficulties of GHRM practices. For the next research, the researcher also can interview other employees within the organisation about their perception of the GRHM practices at the organisation. Furthermore, the researcher can employ a quantitative method to get more significant results based on the perceptions of the employees within the organisation about the GHRM practices. It will show the balanced of how GHRM practices affect their personal life. The objectives of GHRM are all about the awareness of the organisations to save the environment for the future. It shows that the organisations are committed to protecting the environment with the integration of green practice into the HR functions. Next, future research can study the sustainability of the organisation on both performances which are financial and environmental performance. It has been shown at some organizations that when the company practices green in the organisation, it will attract more applicants to apply for employment at the organisation. It will benefit the organisations in both performances according to the research.

\section{ACKNOWLEDGEMENT}

Appreciation is extended to the Malaysian Ministry of Higher Education (MOHE) and University of Malaya Research Ethics Center (UMREC) for granting permission to conduct this research.

\section{FUNDING}

This research was funded by the Malaysian Ministry of Higher Education, under Fundamental Research Grant Scheme (FRGS) [Project number: FP081-2020].

\section{REFERENCES}

Appelbaum, E., Bailey, T., Berg, P., Kalleberg, A. L., \& Bailey, T. A. (2000). Manufacturing advantage: Why highperformance work systems pay off. Cornell University Press.

Aranganathan, P. (2018). Green recruitment: A new-fangled approach to attract and retain talent. International Journal of Business Management \& Research, 8(2), 69-76.

Abd-Rahim, M. H. I., Toh, T.-C., Lew, Y.-L., Ng, S.-J., Goh, K.-C., Mohamed, S., Zainordin, N., \& Kho, M.-Y. (2020). Factors Influencing The Non-Adoption Of Green Building Specifications In Klang Valley Malaysia. International Journal Industrial Management,6,28-39, https://doi.org/10.15282/ijim.6.0.2020.5676

Bailey, T. (1993). Organisational innovation in the apparel industry. Industrial Relations: A Journal of Economy and Society, 32(1), 30-48. https://doi.org/10.1111/j.1468-232X.1993.tb01017.x. 
Barney, J. (1991). Firm resources and sustained competitive advantage. Journal of Management, 17(1), 99-120. https://doi.org/10.1177/014920639101700108.

Cheah, C. K., Prakash, J., \& Ong, K. S. (2020). An integrated OEE framework for structured productivity improvement in a semiconductor manufacturing facility. International Journal of Productivity and Performance Management. 69(5), 1081-1105. https://doi.org/10.1108/IJPPM-04-2019-0176.

Cherian, J., \& Jacob, J. (2012). A study of green HR practices and its effective implementation in the organisation: A review. International Journal of Business and Management, 7(21), 25-33. https://doi.org/10.5539/ijbm.v7n21p25.

Daily, B. F., \& Huang, S. C. (2001). Achieving sustainability through attention to human resource factors in environmental management. International Journal of Operations \& Production Management. 21(12), 15391552. https://doi.org/10.1108/01443570110410892.

Easwaramoorthy, M., \& Zarinpoush, F. (2006). Interviewing for research. Canada Volunteerism Initiative, 1-2.

Garengo, P., Biazzo, S., \& Bititci, U. S. (2005). Performance measurement systems in SMEs: A review for a research agenda. International Journal of Management Reviews, 7(1), 25-47. $\quad$ https://doi.org/10.1111/j.14682370.2005.00105.x.

Gold, N. O., \& Md. Taib, F. (2020). Impact of Corporate Sustainability Reporting Practice on Corporate Performance: A Review of Literature. International Journal of Industrial Management, 8, $19-34$. https://doi.org/10.15282/ijim.8.0.2020.5760

Guerci, M., Longoni, A., \& Luzzini, D. (2016). Translating stakeholder pressures into environmental performance - the mediating role of green HRM practices. International Journal of Human Resource Management, 27(2), 262289. https://doi.org/10.1080/09585192.2015.1065431.

Hueting, R. (2010). Why environmental sustainability can most probably not be attained with growing production. Journal of Cleaner Production, 18(6), 525-530. https://doi.org/10.1016/j.jclepro.2009.04.003.

Ijiri, Y. (1975). Theory of accounting measurement. Studies in Accounting Research 10.

Jabbour, Charbel Jose Chiappetta. (2011). How green are HRM practices, organisational culture, learning and teamwork? A Brazilian study. Industrial and Commercial Training, 43(2), 98-105. https://doi.org/10.1108/00197851111108926.

Jabbour, C., \& Renwick, D. (2020). Organisations as catalysts of sustainable development: greening the workforce for responsible management in the $21 \mathrm{st}$ century. International Journal of Manpower, March. https://doi.org/10.1108/IJM-02-2020-0059.

Jermsittiparsert, K., Sriyakul, T., Sutduean, J., \& Singsa, A. (2019). Determinants of supply chain employees safety behaviours. Journal of Computational and Theoretical Nanoscience, 16(7), 2959-2966. https://doi.org/10.1166/jctn.2019.8202.

Jerónimo, H. M., Henriques, P. L., Lacerda, T. C. de, da Silva, F. P., \& Vieira, P. R. (2020). Going green and sustainable: The influence of green HR practices on the organisational rationale for sustainability. Journal of Business Research, 112, 413-421. https://doi.org/10.1016/j.jbusres.2019.11.036.

Kaplan, R. S., \& Norton, D. P. (2001). Transforming the balanced scorecard from performance measurement to strategic management: Part II. Accounting Horizons, 15(2), 147-160.

Kellner, A., Cafferkey, K., \& Townsend, K. (2019). Ability, Motivation and Opportunity theory: a formula for employee performance?. In Elgar introduction to theories of human resources and employment relations. Edward Elgar Publishing. https://doi.org/10.4337/9781786439017.00029.

Koch, M. J., \& McGrath, R. G. (1996). Improving labor productivity: Human resource management policies do matter. Strategic management Journal, 17(5), 335-354. https://doi.org/10.1002/(SICI)10970266(199605)17:5<335::AID-SMJ814>3.0.CO;2-R.

Kueng, P., Meier, A., \& Wettstein, T. (2001). Performance measurement systems must be engineered. Communications of the Association for Information Systems, 7(3), 1-28. https://doi.org/10.17705/1CAIS.00703.

Melnyk, S. A., Bititci, U., Platts, K., Tobias, J., \& Andersen, B. (2014). Is performance measurement and management fit for the future? Management Accounting Research, 25(2), 173-186. https://doi.org/10.1016/j.mar.2013.07.007.

Mohammed Abdulaal, A., \& Nordin, N. (2020). Review Paper: The Mediating Role of Creativity on The Relationship Between Knowledge Management and Human Resource Management Toward Innovation Performance in The Jordanian SMEs, International Journal of Industrial Management,6,12-18, https://doi.org/10.15282/ijim.8.0.2020.5759

Murari, K., \& Bhandari, M. (2011). Green HR: Going green with pride. Journal of Social Welfare \& Management, 3(34), 35-38.

Mwita, K. M. (2019). Conceptual Review of Green Human Resource Management Practices. East African Journal of Social and Applied Sciences (EAJ-SAS), 1(2), 13-20.

Neely, A., Gregory, M. and Platts, K. (1995), "Performance measurement system design: A literature review and research agenda", International Journal of Operations \& Production Management, 15(4), 80-116. https://doi.org/10.1108/01443579510083622.

Neely, A., Richards, H., Mills, J., Platts, K. and Bourne, M. (1997), "Designing performance measures: a structured approach", International Journal of Operations \& Production Management, 17(11), 1131-1152. https://doi.org/10.1108/01443579710177888. 
Nemati, M., Zheng, Y., \& Hu, W. (2016, July). ISO-14001 Standard and Firms' Environmental Performance: Evidence from the US Transportation Equipment Manufacturers. In Prepared for Presentation at the Agricultural \& Applied Economics Association and Western Agricultural Economics Association Annual Meeting, Boston, Massachusetts. http://dx.doi.org/10.2139/ssrn.2932347.

Olsthoorn, X., Tyteca, D., Wehrmeyer, W., \& Wagner, M. (2001). Environmental indicators for business: a review of the literature and standardisation methods. Journal of Cleaner Production,9(5), 453-463. https://doi.org/10.1016/S0959-6526(01)00005-1.

Opatha, H. H. D. N. P. (2013). Green human resource management a simplified introduction. Proceedings of the HR Dialogue, 1(1), 11-21.

Perron, G. M., Côté, R. P., \& Duffy, J. F. (2006). Improving environmental awareness training in business. Journal of Cleaner Production, 14(6-7), 551-562. https://doi.org/10.1016/j.jclepro.2005.07.006.

Pulakos, E. D. (2004). Performance Management: A roadmap for developing, implementing and evaluating performance management systems (pp. 1-42). Alexandria, VA: SHRM foundation.

Renwick, D. W., Redman, T., \& Maguire, S. (2013). Green human resource management: A review and research agenda. International Journal of Management Reviews, 15(1), 1-14. https://doi.org/10.1111/j.14682370.2011.00328.x.

Sarkis, J., Gonzalez-Torre, P., \& Adenso-Diaz, B. (2010). Stakeholder pressure and the adoption of environmental practices: The mediating effect of training. Journal of Operations Management, 28(2), 163-176. https://doi.org/10.1016/j.jom.2009.10.001.

Shahabadi, A., Samari, H., \& Nemati, M. (2017). The Factors Affecting Environmental Performance Index (EPI) in Selected OPEC Countries. Iranian Economic Review, 21(3), 457-467. https://doi/org/10.22059/IER.2017.62925.

Shaharudin, M. S., Suhaimi, S., Fernando, Y., Wan Husain, W. A. F., \& Suparman, . (2021). Improvement of Green Procurement Performance in the Global Supply Chain: Evidence from Enterprise Resource Planning and Social Network Analysis. International Journal of Industrial Management, 10(1), 173-194. https://doi.org/10.15282/ijim.10.1.2021.6053

Šimberová, I., Chvátalová, Z., Kocmanová, A., Hornungová, J., \& Dočekalová, M. P. (2015). Sustainable value in measuring of corporate sustainability: Approaches and their evaluation. Journal of Security \& Sustainability Issues, 4(3), 241-259.

Tan, S.-H., \& Hong, M. (2020). Economic Growth, Urbanisation And Carbon Emissions: Evidence From Selected Asean Countries. International Journal of Industrial Management, 6,9-16, https://doi.org/10.15282/ijim.6.0.2020.5637

Yong, J. Y., Yusliza, M. Y., Ramayah, T., Chiappetta Jabbour, C. J., Sehnem, S., \& Mani, V. (2020). Pathways towards sustainability in manufacturing organisations: Empirical evidence on the role of green human resource management. Business Strategy and the Environment, 29(1), 212-228. https://doi.org/10.1002/bse.2359.

Yusliza, M.-Y., Yong, J. Y., Tanveer, M. I., Ramayah, T., Noor Faezah, J., Muhammad, Z., Faezah, J. N., \& Muhammad, Z. (2020). A structural model of the impact of green intellectual capital on sustainable performance. Journal of Cleaner Production, 249(119334). https://doi.org/10.1016/j.jclepro.2019.119334.

Yusmani, Y., \& Yusliza Y. (2015). Strategic Green Human Resource Management as a Critical Success Factors for Environmental Performance in Malaysia. Conference on Green Human Resource Management (CGHRM) 2015 , 163-181. 


\section{CONFLICT OF INTEREST}

All authors declare that they have no conflict of interest.

\section{AUTHORS' BIOGRAPHY}

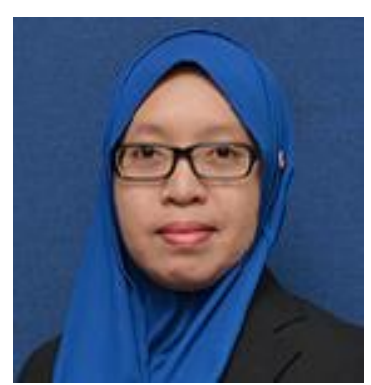

Nurul Liyana Mohd Kamil is a Senior Lecturer at Faculty of Economic and Administration, University of Malaya. She holds a PhD in Human Resource Management from Universiti Sains Malaysia. Her area of expertise is focusing on job performance, innovative work-behaviour, organisational citizenship behaviour, and organisational climate in the public sector, healthcare sector, and banking institution. She can be contacted at Faculty of Economics and Administration, Universiti Malaya, 50603, Wilayah Persekutuan Kuala Lumpur via email at nurulliyana@um.edu.my or phone at +60379673728 .

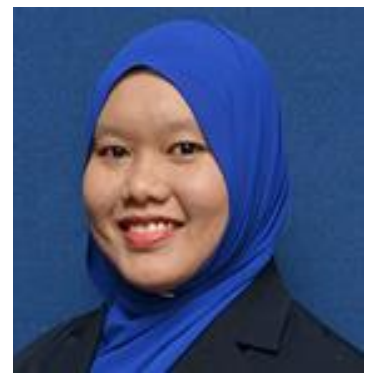

Nur Hairani Abd Rahman is a Senior Lecturer at the Faculty of Economics and Administration, University of Malaya. She receives her PhD in Public Policy from the Universiti Sains Malaysia. Her research interest includes public policy, public administration and governance. She can be contacted at Faculty of Economics and Administration, Universiti Malaya, 50603, Wilayah Persekutuan Kuala Lumpur via email at nurhairani@um.edu.my or phone at +60379673733 .

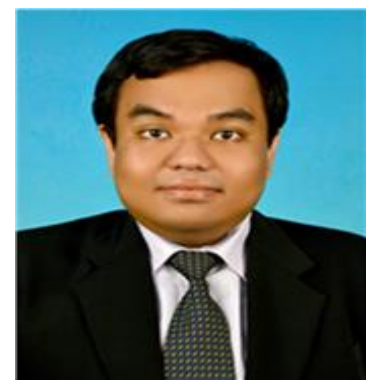

Mohd Hasrul Mat Yusof is a former Master of Public Administration student at Faculty of Economics and Administration, Univesiti Malaya. He can be contacted via email at hasrulyusof77@gmail.com or phone at +0176844326. 